\title{
Persepsi Siswa/i SMK terhadap Iklan Layanan Masyarakat "Narkoba" Trans7 di SMK 58 Jakarta
}

\author{
Ihsan Fahmi ${ }^{1}$, atimah $^{2}$, Mustopa $^{3}$ \\ ${ }^{1,2,3}$ Sekolah Tinggi Ilmu Komunikasi Indonesia Maju \\ Email correspondent: willfahmi@gmail.com
}

\begin{abstract}
Abstrak
Penelitian ini bertujuan untuk menggambarkan persepsi iklan layanan masyarakat narkoba Trans7 pada siswa/i SMK 58 Jakarta. Metode yang digunakan dalam penelitian ini deskriptif kuantitatif dengan desain CrossSectional. Populasi penelitian adalah Siswa/i SMK 58 Jakarta yang berjumlah 79 orang. Sample penelitian ini berjumlah 55 orang $(\mathrm{N}=55)$ dan dipilih menggunakan rumus slovin dengan teknik pengumpulan data yang digunakan dalam penelitian ini dilakukan dengan cara menyebar kuesioner. Analisa data pada penelitan ini menggunakan SPSS versi 25.0. Hasil penelitian menunjukkan bawa dari 55 responden, usia 16 tahun 26 orang (47\%), usia $>16$ tahun sebanyak 29 orang (53\%). Jenis kelamin perempuan 26 orang $(47 \%) \&$ laki-laki 29 orang $(53 \%)$. Tingkat persepsi tidak mengerti 40 orang $(72,2 \%)$ dan yang mengerti sebanyak 15 orang $(27,3 \%)$. Dilihat dari iklan layanan masyarakat yang tidak tertarik sebanyak 28 orang $(50,9 \%)$ dan yang tertarik sebanyak 27 orang $(49,1 \%)$. Kesimpulan dari penelitian ini adalah menggambarkan bahwa siswa/i memahami komponen-komponen dari persepsi dan elemen pada iklan layanan masyarakat narkoba Trans7. Dan untuk meningkatkan iklan layanan masyarakat ini sebaiknya iklan tersebut tidak hanya ditayangkan di televisi tetapi ditayangkan di media lain agar iklan tersebut dapat memberikan informasi kepada masyarakat yang lebih luas agar penyebaran informasinya lebih merata.
\end{abstract}

Kata kunci: narkoba, media, iklan layanan masyarakat, persepsi

\begin{abstract}
This study is to illustrate the perception of public service ads about drugs in the Trans 7 tv station towards vocational students 58 Jakarta. This research uses quantitative descriptive methods and the design of this study is cross-sectional. The study population was 79 students in Vocational High Schools 58 in Jakarta. The sample of this study was 55 people $(N=55)$ and was chosen using the Slovin formula with the data collection technique used in this research being conducted by way of spreading the questionnaire. Analysis of the data in this study using SPSS version 25.0. The results showed that of the 55 respondents who in the age 16th of 26 people (47\%) and $<16$ th of 29 people (53\%). Based on gender, female sex of 26 people (47\%) and male sex of 29 people (53\%). Based on the perception of not understanding of 40 people $(72,2 \%)$ and as many as people understand of 15 $(27,3 \%)$. In terms of community service announcements as many people who are not interested are 28 people (50,9\%) and interested in 27 people (49\%). The conclusions of the results are found that students understood the components of perception and elements in public service announcements about drugs on the Trans $7 \mathrm{tv}$ station. To improve the advertisement should not only be broadcast on television but be broadcast on other media so that the advertisement can provide information to many people.
\end{abstract}

Keywords: drugs, media, public service advertisements, perception 


\section{Pendahuluan}

Menurut Badri penyalahgunaan narkoba dapat dikelompokan menjadi dua bagian, pertama berasal dari faktor individu seperti pengetahuan, sikap kepribadian, jenis kelamin, usia, dorongan kenikmatan, perasaan ingin tahu dan untuk memecahkan persoalan yang dihadapi. Dan yang kedua berasal dari lingkungan seperti pekerjaan, keluarga yang tidak harmonis, sosial ekonomi dan tekanan kelompok. ${ }^{1}$

Hampir semua orang didunia ini tahu akan narkoba, sudah banyak sekali kegiatan- kegiatan yang dilakukan untuk memberantas narkoba, dan dihukum dengan berat. Namun, sampai saat ini masih banyak yang menggunakan narkoba dan lebih banyak tiap waktunya. Upaya pemberantasan narkoba pun sudah sering dilakukan, tetapi masih sedikit kemungkinan untuk menghindari narkoba dari kalangan remaja hingga dewasa, bahkan anak- anak yang masih dibangku sekolah dasar pun banyak yang terjerumus ke dalam penyalahgunaan narkoba, harusnya masyarakat sendiri juga sudah tahu bahaya narkoba bagi tubuh kita dan berbagai dampak lainnya.

Menurut Badan Narkotika Nasional di Indonesia, penyebaran narkoba semakin hari semakin meningkat. Terdapat tiga jenis narkoba yang paling beredar di Indonesia yaitu ganja, sabu-sabu dan ekstasi. Sebagian besar ganja yang beredar di Indonesia berasal dari Aceh. Sebagian kecil ganja berasal dari Papua. Adapun sabu-sabu umumnya berasal dari China dan Iran. Sedangkan ekstasi berasal dari Eropa. Berbagai cara dilakukan sindikat lintas negara untuk memasukan narkoba ke Indonesia melalui darat, laut dan udara. Tingginya penggunaan narkoba di kalangan pelajar disebabkan dua faktor, yaitu dari dalam dan dari luar. Faktor dari dalam biasanya anak-anak remaja menggunakan narkoba sebagai bentuk pelarian dari berbagai masalah. Sedangkan faktor dari luar biasanya mereka terjebak dalam pergaulan bebas yang salah sehingga menjadikan narkoba sebagai bagian dari salah satu lifestyle atau gaya hidup sehari-hari. ${ }^{2}$

NAPZA (Narkotika, Psikotropika,dan Zat Adiktif lain) merupakan bahan/zat/obat yang bila masuk ke dalam tubuh manusia. Bahan/zat yang jika dimasukan dalam tubuh manusia, baik secara diminum, dihirup, maupun disuntikan dapat mengubah pikiran, suasana hati atau perasaan, dan perilaku seseorang. Narkoba dapat menimbulkan ketergantungan baik fisik dan psikologis. Bila narkoba digunakan secara terus menerus dan melebihi takaran yang telah ditentukan maka akan mengakibatkan ketergantungan. Kecanduan inilah yang akan mengakibatkan ganguan fisik seperti berat badan turun drastis, matanya terlihat cekung dan merah, bibir berwarna kehitam-hitaman, tangan dipenuhi binik-bintik merah, dan psikologis menjadi sangat sensitif, mudah bosan, emosi tidak stabil, karena terjadi kerusakan pada sistem syaraf pusat dan organ-organ tubuh seperti jantung, paru-paru, hati dan ginjal. ${ }^{3}$

Salah satu peraturan perundang- undangan yang bersifat imperatif adalah undang-undang nomor 35 Tahun 2009 tentang Narkotika. Undang-Undang ini merupakan perubahan atas Undang-Undang Nomor 22 Tahun 1997 yang dipandang tidak sesuai lagi dengan perkembangan situasi dan kondisi yang berkembang untuk menanggulagi dan memberantasi tindak pidana tersebut. Berdasarkan data Havoscope (pasar gelap) tahun 2018, sabu-sabu dibanderol paling mahal dengan harga satu gramnya sekitar \$203,8 atau Rp 2,5juta, lebih tinggi lima kali lipat dari harga penjualan di tiongkok. Meski illegal, keuntungan dari bisnis gelap narkoba terbilang menggiurkan. Apalagi Indonesia punya harga pasaran lebih tinggi dibanding negara-negara lain di Asia. Oleh karena itu Indonesia menduduki peringkat dua untuk perdagangan gelap narkoba terbanyak dari 6 negara ASEAN. Bisnis narkoba pun menempati posisi ketiga transaksi terbesar dalam pasar gelap Indonesia, mencapai US \$4 miliar per tahun atau 23,05 persen dari total nilai pasar gelap Tanah Air. ${ }^{4}$

Indonesia yang semula menjadi negara transit atau pemasaran sekarang sudah meningkat pula menjadi negara eksportir atau produsen pil berbahaya tersebut. Jenis bahan dasar yang bersifat sintetis untuk membuat pil haram tersebut sangat mudah maupun home industry di duga sudah merebak di kota-kota besar.

Menurut data potensi desa (PODES) 2018 Badan Pusat Statistik (BPS) yang sudah diolah Lokadata beritagar.id, sumber menjadi provinsi dengan sebaran terbanyak. Angkanya naik dari 14,7\% 
pada 2014 menjadi 37,7\% pada 2018 atau ada pertumbuhan sekitar 23,1\% dalam kurung waktu empat tahun. Sedangkan di DKI Jakarta mengalami penurunan dari 47,2\% pada tahun 2014 menjadi 34,5\% pada tahun 2018. Dalam kurung waktu tersebut tercatat wilayah desa atau kelurahan yang ada kejadian penyalahgunaan atau peredaran narkoba. ${ }^{5}$

Dalam kurung waktu lima tahun terakhir Badan Narkotika Nasional Indonesia. Mencatat pada tahun 2014 terdapat 3709 kasus dan 4439 yang menjadi tersangka yang dilaporkan, tahun 2015 terdapat 2443 kasus narkoba dan 3098 tersangka kasus narkoba, tahun 2016 kasus narkoba turun sampai 883 kasus dan 1359 tersangka kasus narkoba, dan angka tersebut meningkat dari tahun ke tahun sekitar $1,3 \%$ sampai $2,2 \%$. Dalam kasus ini kebanyakan remaja yang masih pelajar sampai mahasiswa menjadi korban dari narkoba.

Berdasarkan data p2p.kemkes.go.id menyatakan penyalahgunaan narkoba diperkirakan sebanyak 3,8 juta $-4,1$ juta orang atau sekitar 2,1\% - 2,25\% dari total seluruh penduduk Indonesia yang berisiko terpapar narkoba di tahun -2014 laporan survey BNN Bersama Puslitkes UI tahun 2014. (19)Sedangkan angka angka penyalahgunaan Narkoba dikalangan pelajar di tahun 2018 (dari 13 ibukota provinsi di Indonesia mencapai angka 2,29 juta orang. Salah satu kelompok masyarakat yang rawan terpapar penyalahgunaan narkoba adalah mereka yang berada pada rentang usia 15-35 tahun atau generasi milenial. ${ }^{6}$

Dalam Mahkama Agung Republik Indonesia Pengadilan Negeri Karanganyar Kelas II (pnkaranganyar.go.id) dalam menangani penyalahgunaan narkoba diperlukan upaya yang efektif dan mendasar agar narkoba tidak merambah lebih luas. Badan Narkotika Nasional (BNN) dengan melalui beberapa tahap program yaitu: ${ }^{7}$ (1) Program promotif atau program binaan dimana sasaran pembinaanya adalah masyarakat yang belum memakai atau bahkan mengenal narkoba sama sekali.

(2) Program preventif atau program pencegahan dimana ini ditunjukan kepada masyarakat sehat. Bentuk program preventif ini meliputi kampanye anti penyalahgunaan narkoba memberikan informasi satu arah dari pembicara; penyuluhan seluk beluk narkoba memberikan informasi yang bersifat dialog; Pendidikan dan pelatihan kelompok sebaya; dan Program upaya mengawasi dan mengendalikan produksi dan upaya distribusi narkoba di masyarakat. (3) Program kuratif atau program pengobatan dimana ini ditunjukan kepada para pemakai narkoba. (4) Program represif ini ditunjukan untuk menindak para produsen, bandar, pengedar dan pemakai narkoba secara hukum.

Iklan layanan masyarakat ditunjukan untuk mengubah opini atau persepsi dan meningkatkan kesadaran masyarakat terkait narkoba dan efek dari bahaya dari narkoba tersebut serta sebagai penyebarkan informasi dengan cepat dan efesien. Salah satunya media yang ikut berpartisipasi dalam menangani penyebaran narkoba adalah Trans 7, iklan layanan masyarakat narkoba tersebut sudah ditayangkan mulai awal bulan juli 2019 hingga akhir tahun 2019 di Trans 7, dalam rangka memberikan informasi tentang bahaya narkoba pihak Trans 7 menayangkan iklan narkoba tersebut pada jam-jam primetime. Jam primetime yang dimaks ud adalah pada pagi hari pukul $05.00-08.00$, siang hari pukul 12.00-14.00, sore hari pukul 17.00 - 20.00 pada jam tersebut dimana orang-orang sedang tidak melakukan aktifitas kerja mereka dan lebih memili hiburan yang ditayangkan di televisi.

SMK Negeri 58 Jakarta adalah satu- satunya sekolah seni yang ada di DKI Jakarta dimana semua siswa/i harus bisa menghasilkan sebuah karya dari hasil kerajinan tangan. SMKN 58 Jakarta dulu adalah sekolah teknik menengah atau STM, hampir seluruh siswanya adalah laki-laki dan terdapat kasus pengguna narkoba ini terjadi pada kalangan remaja mulai dari usia 15-18 tahun salah satunya adalah SMKN 58 Jakarta. Pada tahun ajaran 2013- 2014 pernah terjadi kasus penyebaran narkoba dimana salah satu siswa kelas 12 terjaring kasus narkoba dan beritanya menyebar hingga 1 sekolah. Dengan munculnya kasus tersebut banyak banyak sekolah yang melakukan penyuluhan tentang bahaya narkoba salah satu cara yang digunakan adalah dengan menayangkan iklan layanan masyarakat narkoba trans7 tentang bahaya narkoba.

Tujuan penelitian ini untuk mengetahui daya tarik dan persepsi iklan layanan masyarakat narkoba Trans Media terhadap siswa/I SMK Negri 58 Jakarta. 


\section{Metode}

Metode yang digunakan adalah penelitan deskriptif (descriptive research) Metode penelitian menggmbarkan fenomena-fenomena yang ada yang berlangsung pada saat ini atau saat yang lampau serta tidak mengadakan manipulasi atau pengubahan pada variable- variable bebas, tetapi menggambarkan suatu kondisi apa adanya. ${ }^{8}$

Penelitian ini dilakukan di Sekolah Menegah Kejuruan (SMK) Negeri 58 Jakarta. Waktu penelitian mulai dari tanggal 21 Oktober sampai dengan 19 Desember 2019. Populasi dalam penelitian ini adalah seluruh siswa/i SMK 58 Jakarta Jurusan Desain Komunikasi Visual kelas XII. penelitian ini peneliti menentukan sampel dengan cara memperhatikan strata yang ada pada populasi, jadi peneliti menggunakan Proporsional Random Sampling dengan jumlah sampel 55.

Penelitian ini menggunakan dua variabel yaitu variabel independen yaitu persepsi sebagai variabel $\mathrm{X}$ dan variabel dependent yaitu iklan layanan masyarakat sebagai variabel $\mathrm{Y}$ dengan teknik pengumpulan data yang digunakan dalam penelitian ini dilakukan dengan cara menyebar kuesioner. ${ }^{9}$

Defisi oprasional diperlukan untuk menghindari salah pengertian dan menghindari kesalahpahaman persepsi dengan konsep yang ada, supaya terjadi keseragaman landasan berfikir penelitian ini. Dapat ditarik sebuah defisi oprasional, dengan alat ukur kuesioner variabel X dan Y. Dalam penelitian ini variabel $\mathrm{X}$ dengan 7 indikator dan variabel $\mathrm{Y}$ dengan 6 indikator.

Dalam menganalisis data yang diikuti dengan penyajian hipotesis penelitian memiliki langkah sebagai berikut uji validitas. Uji validitas pada variabel Persepsi $(X)$ dengan nilai validitas sebesar 0.266 terdapat 1 item yang gugur yaitu No. 2. Uji validitas pada variabel Iklan Layanan Masyarakat (Y) nilai validitas 0.266 terdapat 1 item yang gugur yaitu No. 8 .

Pada uji reabilitas kedua variabel yaitu X dan Y dengan nilai sebesar 0.266, kedua variabel tidak ada item yang gugur. Ketetapa suatu hasil pengukuran/assessment dalam penelitian akan ditentukan oleh berbagai faktor, antara lain oleh konsistensi, stabilitas, atau ketelitian alat ukur/inventori yang digunakan Reabilitas merupakan konsistensi atau kestabilan skor suatu instrument penelitian terhadap individu yang sama dan diberikan dalam waktu yang berbeda.

Analisis univariat adalah anaisis yang dilakukan terhadap masing-masing variabel dan hasil penelitian dan dianalisis untuk mengetahui distribusi dan persentase dari tiap variabel. Analisis univariat bertujuan untuk menjelaskan atau mendeskripsikan karakteristik setiap variable penelitian. Analisis ini dilakukan untuk semua variable yang diteliti. Secara teknis pada dasarnya analisis merupakan kegiatan meringkas kumpulan data menjadi ukuran tengah dan ukuran variasi. Selanjutnya membandingkan hubungan-hubungan tersebut antara satu kelompok subjek dan subjek yang lain, sesuai dengan tujuan yang ingin dicapai dalam analisis. Peringkasan data menggunakan data analisis deskriptif standar SPSS untuk distribusi frekuensi dengan ukuran presentase atau proporsi. Pada umumnya dalam analisis univariat hanya menghasilkan distribusi frekuensi dan presentase dari tiap variabel. ${ }^{10}$

Kegiatan meringkas kumpulan data menjadi ukuran tengah dan ukuran variasi. Setelah itu, membandingkan hubungan- hubungan tersebut antara satu kelompok subjek dan subjek lainnya sesuai dengan tujuan yang ingin dicapai dalam analisis deskriptif menggunakan software SPSS versi 25.0 untuk distribusi frekuensi dengan presentase atau proporsi. Dalam analisis univariat hanya menghasilkan distribusi frekuensi dan presentase dari tiap variabel. 


\section{JIKOM}

Jurnal Ilmiah Komunikasi

Volume 12, No.01, Maret. 2020

Hasil

Tabel 1 Hasil Gambaran Terpaan Iklan Layanan Masyarakat Narkoba Trans 7.

\begin{tabular}{lcc}
\hline Karakterisik Responder & $\begin{array}{c}\text { Frekuensi } \\
\text { (F) }\end{array}$ & $\begin{array}{c}\text { Persentase } \\
\text { (\%) }\end{array}$ \\
\hline Usia & 26 & 47 \\
$\mathbf{1 6}$ & 29 & 53 \\
$>\mathbf{1 6}$ & 55 & $\mathbf{1 0 0}$ \\
Jumlah & & \\
Jenis Kelamin & 26 & 47 \\
Perempuan & 29 & 53 \\
Laki-laki & 55 & $\mathbf{1 0 0}$ \\
Jumlah & & \\
Persepsi & 40 & 72.7 \\
Tidak Mengerti & 15 & 27.3 \\
Mengerti & $\mathbf{5 5}$ & $\mathbf{1 0 0}$ \\
Jumlah & & \\
Kualitas Gambar ILM & 28 & 50.9 \\
Tidak Menarik & 27 & 49.1 \\
Menarik & $\mathbf{5 5}$ & $\mathbf{1 0 0}$ \\
Jumlah & & \\
\hline
\end{tabular}

Sumber : Data Primer yang disederhanakan Tahun 2020

Dari tabel 1 dapat dilihat responder dengan usia 16 tahun 26 orang (47\%), >16 tahun 29 orang (53\%). Responder yang berjenis kelamin perempuan 26 orang (47\%) dan laki- laki 29 orang (53\%). Dari 55 responden, yang berpendapat memiliki persepsi iklan tersebut tidak memahami ada 40 orang $(72,7 \%)$, sedangkan yang berpendapat memiliki persepsi iklan tersebut mengerti ada 15 orang $(27,3 \%)$. Dari 55 responden, yang berpendapat memiliki iklan layanan masyarakat tersebut tidak menarik ada 28 orang $(50,9 \%)$, sedangkan yang berpendapat memiliki iklan layanan masyarakat tersebut menarik ada 27 orang $(49,1 \%)$.

Berdasarkan tabel di atas dapat disimpulkan bahwa responden sering melihat iklan anti narkoba. Iklan layanan masyakarat ini mampu menarik perhatian responden khususnya remaja, dari segi narasi (VO) pada iklan ini terdengar jelas oleh responden. Iklan layanan masyarakat ini pun diterima dan tertarik responden untuk melihat iklan ini. Dari segi penyampaian pesan, iklan layanan masyarakat ini dapat dipahami isi pesan yang ingin disampaikan dan responden pun mampu menganalisa informasi yang disampaikan oleh iklan tersebut. Iklan layanan masyarakat ini pun dapat mempengaruhi pandangan masyarakat terhadap narkoba, responden pun bersedia memberikan informasi iklan tersebut kepada orang lain..$^{20}$

Dilihat dari kondisi Indonesia saat ini, iklan layanan masyarakat tersebut, sesuai dengan keadaan Indonesia saat ini. Iklan ini pun dapat ditunjukkan kepada semua kalangan umur. Namun, menurut responden iklan ini memiliki durasi yang terlalu lama. Sekalipun iklan layanan masyarakat ini mampu menyadarkan responden akan bahaya dari narkoba dan mendorong responden untuk menjauhi narkoba. ${ }^{15}$ 


\section{Pembahasan}

Periklanan merupakan sarana penyampaian pesan suatu produk/jasa dari pengiriim pesan (lembaga/produsen) ke penerima pesan dengna maksud untuk menarik perhatian, menggugah utnuk menyetujui dan mengikuti. Iklan layanan masyarakat mengajak audiens untuk ikut menyetujui/menyarankan penerima pesan untuk dapat melakukan tindakan yang diinformasikan. ${ }^{11}$

Iklan dimaksudkan untuk dapat dilihat dan mempengaruhi pemirsa, berdasarkan yang melihat iklan layanan anti narkoba hampir semua siswa/i sering melihat Iklan Layanan Masyarakat Anti Narkoba yang artinya bahwa penyebaran informasi tentang bahaya narkoba dikalangan pelajar berjalan dengan baik. Hal ini terbukti dari banyaknya siswa/i yang mengtahui tentang Iklan Layanan Masyarakat Anti Narkoba tersebut. Pengambilan gambar pada dari Iklan Layanan Masyarakan Anti Narkoba menunjukan jika siswa/i merasa tertarik untuk menyimak iklan tersebut. Hal ini membuktikan jika sinematografis dari Iklan Layanan Masyarakat Anti Narkoba Trans7 memiliki kualitas yang baik dan membuat siswa/i bisa memahami seperti apa pengambilan gambar yang baik itu seperti apa. ${ }^{16}$

Hasil dari kualitas audio yang ada pada Iklan Layanan Masyarakan Anti Narkoba Trans7 sangat baik dengan pernyataan bahwa semua siswa/i mengatakan jika audio terdengar dengan jelas. Dengan adanya kualitas audio yang baik membuat proses penyampaian informasi mengenai bahaya narkoba berjalan dengan lebih baik lagi, karena siswa/i merasa nyaman dengan suara VO yang ada. Siswa/i juga dapat lebih memahami lagi seperti apa intonasi yang baik dan enak didengar dalam membuat sebuah narasi. ${ }^{14}$

Hasil dari Iklan Layanan Masyarakan Anti Narkoba Trans7 dalam menarik perhatian siswa/i sudah berhasil. Hal ini tentu saja terjadi karena kualitas gambar dan audio dari Iklan Layanan Masyarakan Anti Narkoba Trans7 sangat bagus, seperti yang sudah dijelasakan sebelumnya. Dengan komposisi audio dan visual yang baik dari Iklan Layanan Masyarakan Anti Narkoba Trans7 siswa/i dapat. menjadikan iklan ini menjadi referensi mereka dalam membuat sebuah iklan. ${ }^{13}$ Iklan layanan masyarkat ini mengaplikasikan teori SOR (Stimulus, Organism, Response), dimana melihat sikap, opini, perilaku, afeksi yang terjadi dari objek. Stimulus response ini timbul dari reaksi khusus terhadap yang diharapkan, diperkirakan. ${ }^{12}$

Hasil dari penyampaian pesan Iklan Layanan Masyarakan Anti Narkoba Trans7 berjalan dengan baik karena semua siswa/i mengerti dengan semua pesan yang disampaikan. Dengan tersampaikan pesan tentang bahaya narkoba akan mebuat siswa/i lebih berhati-hati dengan narkoba. Dari Iklan Layanan Masyarakan Anti Narkoba Trans7 ini siswa/i juga dapat belajar jika membuat sebuah iklan bukan hanya harus memiliki visusal dan audio yang baik, tapi juga pesan yang ingin disampaikan juga harus berhasil dimasukana dalam membuat sebuah iklan. Hasil dari pemahaman Iklan Layanan Masyarakan Anti Narkoba Trans7 menunjukan jika semua siswa memahami isi iklan tersebut. Pemahaman tentang bahaya narkoba dari Iklan Layanan Masyarakan Anti Narkoba Trans7 oleh siswa/i bisa terjadi dengan semua unsur dan standar membuat iklan yang baik dan menarik sudah dilakukan dalam membuat iklan ini.

Dalam melakukan analisa terhadap Iklan Layanan Masyarakan Anti Narkoba Trans7 siswa/i tersebut dapar menganalisa dengan baik informasi yang disampaikan. Dengan dapat menganalisa dengan baik informasi pada Iklan Layanan Masyarakan Anti Narkoba Trans7 membuat siswa/i mempunyai kesadaran diri untuk tetap menjauhkan diri dari narkoba. Dengan adanya pernyataan ini artinya siswa/i telah memahami dengan baik bahaya narkoba serta ada kemungkinan para siswa/i telah menerima informasi mengenai bahaya narkoba sebelum iklan ini muncul. Kemungkinan siswa/i memperoleh informasi terlebih dahulu dikarena tidak semua orang bisa langsung setuju begitu saja terhadap informasi yang baru saja mereka dengar.

Siswa/i berpendapat jika Iklan Layanan Masyarakan Anti Narkoba Trans7 dapat mempengaruhi pandangan masyarakat tentang bahaya narkoba. Hal ini bisa terjadi karena hampir semua siswa/i yang menyaksikan Iklan Layanan Masyarakan Anti Narkoba Trans7 menyatakan mengubah pandangan mereka tentang bahaya narkoba, dan hal tersebut juga bisa bekerja untuk orang lain yang menyaksikan iklan ini. Hampir semua siswa/i menyatakan ingin berpartisipsi untuk memberikan informasi tentang 
bahaya penggunaan narkoba. Hal ini merupakan hal yang positif untuk menunjukan kemampuan komunikasi dan sosial siswa/i terhadap orang-orang disekitar mereka.

Text yang muncul pada Iklan Layanan Masyarakan Anti Narkoba Trans7 sudah sesuai dengan Ejaan Yang Disempurnakan (EYD), terbukti dengan siswa/i memahami arti dari text yang muncul pada iklan ini. Dengan mengertinya siswa/i pada text yang muncul maka itu menandakan jika kemampuan siswa/i dalam menggunakan bahasa Indonesia yang baik dan benar sangat bagus. Komposisi warna pada tulisan yang muncul di Iklan Layanan Masyarakan Anti Narkoba Trans7 memiliki kontras dan komposisi yang baik sehingga membuat siswa/i mudah untuk melihat dan membacanya. Dengan adanya iklan ini siswa/i dapat mempelajari seperti apa komposisi dan kontras warna yang dapat dibaca dan dinikmati dengan baik.

Visual yang ditampilkan oleh Iklan Layanan Masyarakan Anti Narkoba Trans7 menujukan keadaan sebernanya kondisi masyarakat Indonesia. Siswa/i mengetahui hal ini yang artinya proses sosoalisasi mereka terhadap linkungan berjalan dengan baik, karena mereka mengetahui seperti apa kebidupan sekitar mereka (masyarakat Indonesia). Setiap iklan pasti mempunyai sebuah pesan pada Iklan Layanan Masyarakan Anti Narkoba Trans7 telah berhasil menyampaikan pesan mereka kepada masyrakat Indonesia. Jika siswa/i bisa memahami dengan baik isi pesan tersebut tentu saja orang dewasa dan remaja lainnya mengerti tentang isi pesan tersebut. Narasi yang baik akan membantu proses penyampaian isi iklan, dalam Iklan Layanan Masyarakan Anti Narkoba Trans7 siswa/i berpendapat jika suara yang dihasilkan dapat didengar dan dipahami dengan baik. Dengan suara yang jelas dan mudah dipahami akan membuat orang-orang yang memiliki kekurangan dalam melihat bisa memahami isi pesan tersebut walau dari suaranya saja.

Siswa/i berpendapat jika Iklan Layanan Masyarakan Anti Narkoba Trans7 menggunakan format elktronik lebih mudah dipahami. Iklan bentuk ini bisa dinikmati oleh semua orang dikala waktu senggang, karena zaman sekarang ini orang-orang tidak bisa lepas dari media elektronik. Hasil Iklan Layanan Masyarakan Anti Narkoba Trans7 yang ditayangkan ini bisa masuk ke semua kalanganan. Iklan ini bisa masuk ke semua kalangan karena siswa/i yang melihat iklan ini berpendapat jika tidak ada hal- hal yang tidak sesuai dengan kaidah iklan dan artinya untuk kalangan remaja dan dewasa tidak ada masalah. Durasi Iklan Layanan Masyarakan Anti Narkoba Trans7 terlali lama, iklan ini memiliki durasi lebih dari 1 menit. Durasi sebuah iklan elektronik sebaiknya tidak kurang dari 30 detik dan tidak lebih dari 1 menit. Iklan Layanan Masyarakan Anti Narkoba Trans7 membuat siswa/i merasa bosan karena panjangnya durasi iklan.

Siswa/i berpendapat jika Iklan Layanan Masyarakan Anti Narkoba Trans7 dapat menyadarkan orang tentang bahaya dari narkoba. Jika iklan ini bisa menyadarkan siswa/i tentang bahaya narkoba, artinya iklan ini telah dikemas dengan baik mulai dari audio, visual dan informasi yang perlu diketahui oleh masyarakat. Setelah menyaksikan Iklan Layanan Masyarakan Anti Narkoba Trans7 siswa/i berpendapat jika narkoba itu berbahaya dan harus di jauhi. Iklan ini memiliki semua element-element iklan yang dapat dinikmati dan mengedukasi masyarakat sehingga menyadarkan masyarakat tentang bahaya narkoba.

\section{Kesimpulan}

Berdasarkan hasil penelitian yang dilakukan mengenai persepsi siswa/i SMKN 58 jakarta jurusan Desain Komunikasi Visual kelas XI dan XII terhadap iklan layanan masyarakat narkoba dapat disimpulkan siswa/i SMK Negeri 58 Jakarta memahami komponen-komponen dari persepsi dan elemen pada iklan layanan masyarakat narkoba trans7 di SMK Negeri 58 Jakarta. Hasil dari penelitian ini menunjukan bahwa siswa/i SMKN 58 Jakarta lebih memahami persepsi iklan dibandingkan dengan elem-elemen yang ada pada iklan.

\section{References}

1. Rahmadika K. Penyalahgunaan Narkoba Pada Warga Binaan Di Rutan Kelas 1 A Surakarta. J Kesehat Masy.;III:224-34;2018 


\section{JIKOM \\ Jurnal Ilmiah Komunikasi}

Volume 12, No.01, Maret. 2020

2. Lusia Sinta Herindrasti V. Drug-free ASEAN: Tantangan Indonesia dalam Penanggulangan Penyalahgunaan Narkoba. J Hub Int. 2018;7(1):24.

3. Sholihah Q. Efektivitas Program P4Gn Terhadap Pencegahan Penyalahgunaan Napza. J Kesehat Masy;2015

4. W. Harahap, Syaiful. Beli Sabu Jakarta dan Makassar Rp 10,5 - 14,2 Juta _ Tagar.

5. Statistik BP. Statistik Hasil Pendataan Potensi Desa (Podes). Badan Pus Stat.;2018

6. Direktorat Pencegahan dan Pengendalian Masalah Kesehatan Jiwa dan NAPZA. LAKIP: Direktorat Pencegahan dan Pengendalian Masalah Kesehatan Jiwa dan NAPZA. Ditjen P2P [Internet]. 2018;26:1-

7. 54. Tersedia pada: http://p2p.kemkes.go.id/wp- content/uploads/2018/04/LAKIP-KESWA- 2017.pdf ;2017

8. Karanganyar P. Pencegahan Penyalahgunaan Narkotika. Jakarta: Tim It Pn Karanganyar.

9. A. Saepul EB. Metode Penelitian Kuantitatif Aplikasi dalam Pendidikan - Asep Saepul Hamdi, E. Bahruddin - [Internet]. Metode Penelitian Kuantitatif Aplikasi dalam Pendidikan. Yogyakarta: Penerbit Deepublis; 2015

10. Yusuf AM. Metode Penelitian Kuantitatif, Kualitatif \& Penelitian Gabungan. hal. xii, 480 hlm.;2016

11. Geometry R, Analysis G. Notoatmodjo S. Metodologi Penelitian Kesehatan. Ed Rev. Jakarta: Rineka Cipta;. Society. Jakarta: Rhieka Cipta; 2010

12. Larasati J. Analisis Presuposisi Pada Bahasa Spanduk Iklan Warung Soto: Kajian Pragmatik. Univ muhammadiyah surakarta; 2015

13. Kurniawan D. Komunikasi Model Laswell Dan Stimulus-Organism-Response Dalam Mewujudkan Pembelajaran Menyenangkan. J Komun Pendidik;2018;2(1):60.

14. Nanang Martono, metode. 2010. PenelitianKuantitatif Analisis Isi Dan Analisis Data Sekunder. Jakarta:Rajawali Pres.

15. Arikunto, S. Prosedur Penelitian Suatu Pendekatan Praktik. Jakarta:Rineka Cipta;2016

16. Yusup F. Uji. 2018. Vliditas dan Reabilitas Intrumen Penelitian Kuantitatif. J Tarb J Ilmu Kependidikan.

17.Zakina. Nilai Estetik Batik Tulis Pewarna Alam Karya Industri Kebon Indah Bayat, Kelaten Jawa Tengah.Universitas Negeri Yogyakarta;2015

18. Agus F. Tangyong. Pengembangan Anak Usia Taman Kanak-Kanak. Jakarta: Grasindo;2010

19. Sugiarti. Estetika Dalam Novel Jatisaba Karya Ramayda Akmal. Universitas Muhamadiah Malang;2016

20. Fatimah, Fatimah. "Komunikasi Persuasif Agen Asuransi Dalam Merekrut Calon Agen (Studi Kasus Tentang Perekrutan Calon Agen Dalam Meningkatkan Penjualan Polis di Asuransi PT. AXA)." Jurnal Ilmiah Komunikasi (JIKOM) STIKOM IMA 10.02 (2018): 110-116 